\title{
Efficacy of extracts of Celastrus orbiculatus in suppressing migration and invasion by inhibiting the EZH2/ROCK1 signaling pathway in human nasopharyngeal carcinoma
}

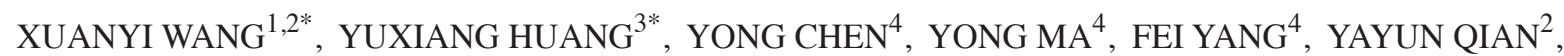 \\ XIAOJUN DAI ${ }^{5}$, LEDE TAO $^{2}$, HAIBO WANG $^{2}$, RENHUA GUO $^{6}$ and YANQING LIU ${ }^{2}$ \\ ${ }^{1}$ Department of Rheumatology, Clinical Medical College, Yangzhou University, Yangzhou, Jiangsu 225000; \\ ${ }^{2}$ School of Medicine, Institute of Traditional Chinese Medicine and Western Medicine, Yangzhou University, Yangzhou, \\ Jiangsu 225009; Departments of ${ }^{3}$ Oncology and ${ }^{4}$ Function Examination, Clinical Medical College, Yangzhou University; \\ ${ }^{5}$ Department of Oncology, TCM Clinical Medical College of Yangzhou University, Yangzhou, Jiangsu 225000; \\ ${ }^{6}$ Department of Oncology, The First Affiliated Hospital of Nanjing Medical University, Nanjing, Jiangsu 210029, P.R. China
}

Received May 22, 2016; Accepted March 23, 2017

DOI: $10.3892 / \mathrm{ol} .2018 .8149$

\begin{abstract}
Celastrus orbiculatus extract (COE) has been used in folk medicine in China for the treatment of a number of diseases. In the laboratory, COE exhibits a variety of anticancer functions, including inhibition of metastasis. However, the underlying molecular anti-metastatic mechanism in nasopharyngeal carcinoma (NPC) cells remains unclear. The aim of the present study was to determine whether the anti-metastatic effect of COE was involved in inhibiting migration and invasion of human NPC cells. In vitro, cell viability and apoptosis of 5-8F cells were analyzed using an MTS assay and flow cytometry, respectively. Invasion and migration of 5-8F cells were analyzed using a Transwell assay. Protein and mRNA expression levels of 5-8F cells were analyzed by western blot analysis and the reverse transcription-quantitative polymerase chain reaction, respectively. COE significantly decreased cell viability in 5-8F cells and inhibited enhancer of zeste homolog 2 (EZH2) and Rho-associated coiled coil-containing protein kinase 1 (ROCK1) expression at the mRNA and protein levels. Furthermore, $\mathrm{COE}$ decreased the migration and invasion of $5-8 \mathrm{~F}$ cells in a dose-dependent manner. The results of the present study suggested that $\mathrm{COE}$ prevents migration and invasion by suppressing the EZH2/ROCK1 signaling
\end{abstract}

Correspondence to: Professor Yanqing Liu, School of Medicine, Institute of Traditional Chinese Medicine and Western Medicine, Yangzhou University, 88 University South Road, Yangzhou, Jiangsu 225009, P.R. China

E-mail: liuyq@yzu.edu.cn

*Contributed equally

Key words: Celastrus orbiculatus, nasopharyngeal carcinoma, enhancer of zeste homolog 2, Rho-associated coiled-coil containing protein kinase 1 , invasion pathway in NPC cells. On the basis of the results of the present study, COE may be a novel anticancer agent for the treatment of metastasis in NPC.

\section{Introduction}

China has the highest incidence and mortality rate of nasopharyngeal carcinoma (NPC), a type of malignant epithelial cell tumor, worldwide (1). NPC exhibits decreased differentiation and a high metastatic nature which frequently causes local regional recurrence and distant metastasis in patients (2), and is the primary reason for failure of treatment. Therefore, it is important to investigate the underlying molecular mechanism of migration and invasion in NPC.

The enhancer of zeste homolog 2 (EZH2) is a core component of the Polycomb repressive complex 2 which possesses a highly conserved SET domain with histone methyltransferase activity. Previous studies have identified that EZH2 was overexpressed in a variety of carcinomas including NPC, prostate cancer and breast cancer. The expression levels of EZH2 were associated with tumor size, depth of invasion, tumor stage, lymph node metastasis, migration and invasion ability, suggesting that EZH2 had the potential to be a novel diagnosis biomarker and a target for antitumor therapy in NPC (3-5).

Rho-associated coiled-coil-containing protein kinase (ROCK) is a RhoA downstream effector protein. ROCK1 is one of the isoforms of ROCK and serves a critical role in the regulation of cell migration and the maintenance of cell migration $(6,7)$.

Previous studies have demonstrated that an ethyl acetate extract of Celastrus orbiculatus (COE), a traditional Chinese herb, has a marked antitumor effect in liver cancer, gastric cancer and other tumors (8-10). In addition, it has been revealed that $\mathrm{COE}$ is able to inhibit tumor metastasis in gastric cancer (8). The results of these studies suggested that COE may also have the ability to inhibit the invasion and metastasis of NPC cells, the validation of which was an aim of the present study. 
In the present study, the effects of COE on migration and invasion in vitro were investigated, in addition to the underlying molecular mechanism. The results indicated that $\mathrm{COE}$ inhibited the invasion by suppressing the EZH2/ROCK1 signaling pathway in NPC cells. Therefore, it is suggested that COE may have therapeutic effects against NPC via the EZH2/ROCK1 signaling pathway.

\section{Materials and methods}

Reagents and antibodies. RPMI-1640 medium and fetal bovine serum (FBS) were acquired from Gibco; Thermo Fisher Scientific, Inc. (Waltham, MA, USA). The Cell Titer 96 Aqueous One solution cell viability assay (MTS assay) was purchased from Promega Corporation (Madison, WI, USA). Matrigel was purchased from BD Biosciences (San Jose, CA, USA). Primary antibodies used were: Rabbit anti-EZH2 (cat. no. ab186006; 1:1,000; Abcam, Cambridge, MA, USA), rabbit anti-ROCK1 (cat. no. ab45171; 1:2,000; Abcam) and rabbit anti- $\beta$-actin (cat. no. 4970; 1:1,000; Cell Signaling Technology, Inc., Danvers, MA, USA). The secondary antibody used was: Horseradish peroxidase (HRP)-conjugated goat anti-rabbit immunoglobulin (Ig) G (cat. no. HA1001-100; 1:2,000; HuaAn Biotechnology Co., Hangzhou, China). Chemical reagents used were: 3-Deazaneplanocin A (DZNeP; Sigma-Aldrich; Merck KGaA, Darmstadt, Germany) and dimethyl sulfoxide (DMSO; Sigma-Aldrich; Merck KGaA). Other chemicals used were of analytical grade from commercial sources.

Plant materials. Plant materials were purchased from Guangzhou RiboBio Co., Ltd. (Guangzhou, China). COE was obtained in the Department of Chinese Materia Medica Analysis in China Pharmaceutical University (Nanjing, China), according to a previously published protocol $(11,12)$. The resultant COE micropowder was dissolved in DMSO and diluted with RPMI-1640 medium to various concentrations $(6.25,12.5,25,50$ and $100 \mu \mathrm{g} / \mathrm{ml})$.

Cell culture. The human NPC cell line 5-8F was a gift from Fudan University Cancer Hospital (Shanghai, China). The cell line was maintained in RPMI-1640 medium and supplemented with $10 \% \mathrm{FBS}, 100 \mathrm{U} / \mathrm{ml}$ penicillin and $100 \mathrm{mg} / \mathrm{ml}$ streptomycin at $37^{\circ} \mathrm{C}$ in a humidified atmosphere containing $5 \% \mathrm{CO}_{2}$.

MTS cytotoxicity assay. The Cell Titer 96 Aqueous One solution cell viability assay (MTS assay) was performed according to the manufacturer's protocol. Cells were seeded in 96-well plates (100 cells/well) and incubated at $37^{\circ} \mathrm{C}$ overnight for attachment. Subsequently, cells were treated with various doses of $\operatorname{COE}(0,6.25,12.5,25,50$ and $100 \mu \mathrm{g} / \mathrm{ml})$ for $24 \mathrm{~h}$. A $20 \mu \mathrm{l}$ volume of MTS reagent was added to each well and incubated at $37^{\circ} \mathrm{C}$ for $2 \mathrm{~h}$. Subsequently, the absorbance was measured at $450 \mathrm{~nm}$ using a microplate reader.

Assessment of apoptosis by flow cytometry. The Annexin V-fluorescein isothiocyanate (FITC) apoptosis detection assay was performed according to the manufacturer's protocol (Bipec Biopharma Corporation, Cambridge, MA, USA). After $24 \mathrm{~h}$ of incubation at $37^{\circ} \mathrm{C}$ with $\mathrm{COE}$, cells were harvested using trypsin and washed twice in PBS. Cells were then re-suspended in $400 \mu \mathrm{l}$ with $1 \mathrm{X}$ binding buffer at a concentration of $1 \times 10^{6}$ cells $/ \mathrm{ml}$ prior to the addition of $5 \mu \mathrm{l}$ Annexin V-FITC. Cells were then vortex-mixed and incubated for $15 \mathrm{~min}$ at between 4 and $8^{\circ} \mathrm{C}$ in the dark. A $10 \mu \mathrm{l}$ volume of propidium iodide was added to each tube before incubation for another $5 \mathrm{~min}$ at between 4 and $8^{\circ} \mathrm{C}$ in the dark. The stained cells were analyzed using flow cytometry by FlowJo version 7.6 software (BD Biosciences).

Cell invasion and migration assays. Cell invasion and migration assays were performed using a Transwell membrane (Corning Incorporated, Corning, NY, USA) according to the manufacturer's protocol. In the invasion assay, Matrigel was applied to the upper chamber. Following treatment with various concentrations $(0,12.5,25$ and $50 \mu \mathrm{g} / \mathrm{ml})$ of COE, $5-8 \mathrm{~F}$ cells $\left(1 \times 10^{5} /\right.$ well $)$ were seeded into the upper chamber. RPMI-1640 medium containing $10 \% \mathrm{FBS}$ was added to the lower chamber. After $24 \mathrm{~h}$ of incubation at $37^{\circ} \mathrm{C}$, cells on the upper membrane surface were removed using a cotton swab and cells on the lower membrane surface were fixed with $4 \%$ paraformaldehyde and stained with crystal violet. The controls of these experiments were cells treated with $0 \mu \mathrm{g} / \mathrm{ml}$ COE. The number of invading cells was counted for each chamber in five random fields (magnification, $\mathrm{x} 200$ ) by an Olympus IX73 fluorescence microscope (Olympus Corporation, Tokyo, Japan) and were captured by digital camera (Olympus Corporation). For the migration assays, the procedures were carried out in the same way, with the exception that the upper membrane was not coated with Matrigel. Each experiment was performed three times.

Quantification of ROCK1 mRNA expression by reverse transcription-quantitative polymerase chain reaction (RT-qPCR). Total RNA was extracted from the COE-treated cells using the TRIzol ${ }^{\circledR}$ reagent (Life Technologies; Thermo Fisher Scientific, Inc.), and RT was performed in a $20 \mu \mathrm{l}$ reaction with $200 \mathrm{ng}$ total RNA using the Two Step RT PCR kit (Takara Biotechnology Co., Ltd., Dalian, China). The RNA concentration was assessed by measuring the absorption (A260/A280) on the NanoDrop Spectrophotometer ND-1000 (NanoDrop, Wilmington, DE, USA). RT was performed under the following conditions: $37^{\circ} \mathrm{C}$ for $15 \mathrm{~min}$, $85^{\circ} \mathrm{C}$ for $5 \mathrm{sec}$, and then held at $4^{\circ} \mathrm{C}$ until use. RT-qPCR was performed in triplicate using SYBR Premix Ex Taq ${ }^{\mathrm{TM}}$ kit (Takara Biotechnology Co., Ltd., Dalian, China) on a LightCycler $^{\circledR} 480$ Real-Time PCR system. The primers used are presented in Table I. qPCR was performed under the following conditions: Initiation step at $95^{\circ} \mathrm{C}$ for $30 \mathrm{sec}$ for one cycle, denaturation step at $95^{\circ} \mathrm{C}$ for $5 \mathrm{sec}$ and $60^{\circ} \mathrm{C}$ for $30 \mathrm{sec}$ for 40 cycles, annealing at $95^{\circ} \mathrm{C}$ for $5 \mathrm{sec}$ and $60^{\circ} \mathrm{C}$ for $1 \mathrm{~min}$ for one cycle, and an elongation step at $50^{\circ} \mathrm{C}$ for $30 \mathrm{sec}$ for 1 cycle. mRNA levels of EZH2 and ROCK1 were measured by the relative fluorescent intensity to the internal control $\beta$-actin using the $2^{-\Delta \Delta \mathrm{Cq}}$ method (13).

Western blot analysis. Protein expression levels were analyzed by western blot analysis. Experiments were performed at least three times. The cells were scraped into $0.3 \mathrm{ml}$ lysis buffer on ice. Cell debris was removed by centrifugation $(12,000 \mathrm{x} \mathrm{g}$, $\left.4^{\circ} \mathrm{C}, 10 \mathrm{~min}\right)$. The protein concentrations were quantified using the Bradford method. A total of $30 \mu \mathrm{g}$ protein/lane 
Table I. Primers for reverse transcription-quantitative polymerase chain reaction analysis.

\begin{tabular}{lll}
\hline Gene & \multicolumn{1}{c}{ Forward primer sequence } & \multicolumn{1}{c}{ Reverse primer sequence } \\
\hline EZH2 & 5'-TCAAAGAACTACCTGGATGCTGT-3' & 5'-CTTGAGCTGTCTCAGTCGCA-3' \\
ROCK1 & 5'-CCAACAGTCCTTGGGTTGTTCA-3' & 5'-TTTCAGGCACATCATAGTTGCTC-3' \\
$\beta$-actin & 5'-TTCCTTCCTGGGCATGGAGT-3' & 5'-TCTTCATTGTGCTGGGTGCC-3' \\
\hline
\end{tabular}

A

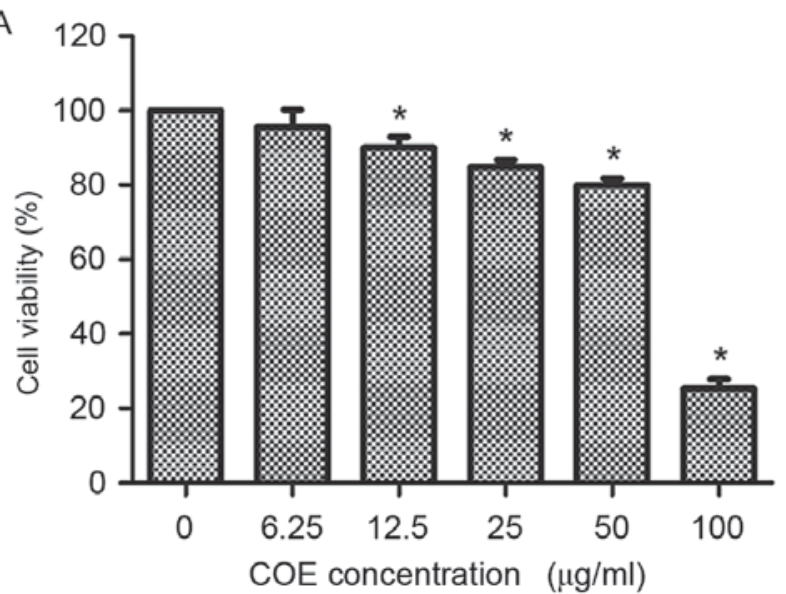

B

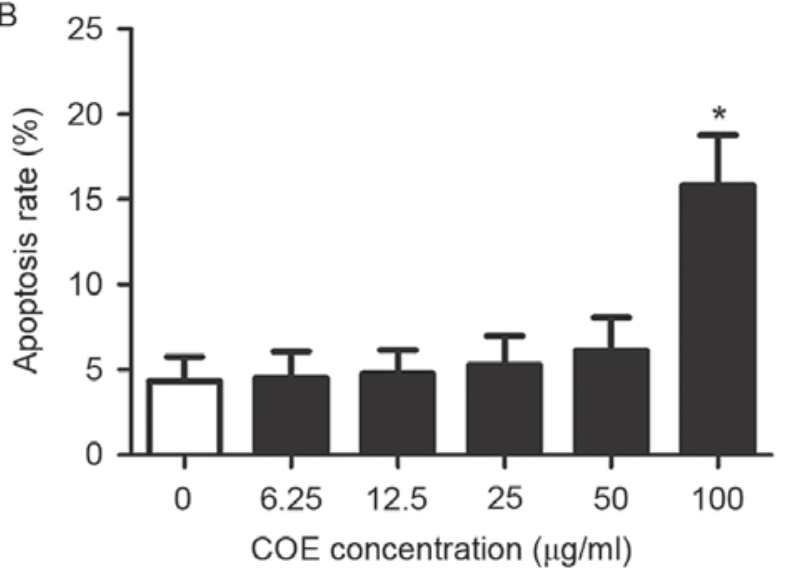

Figure 1. (A) Effect of COE on viability of $5-8 \mathrm{~F}$ cells. $5-8 \mathrm{~F}$ cells were treated for $24 \mathrm{~h}$ with various concentrations $(0,6.25,12.5,25,50 \mathrm{and} 100 \mu \mathrm{g} / \mathrm{ml})$ of $\mathrm{COE}$. A viability assay was used to determine viability relative to the control cells. (B) Effect of COE on induction of apoptosis in 5-8F cells. Cells were treated with various concentrations $(0,6.25,12.5,25,50$ and $100 \mu \mathrm{g} / \mathrm{ml})$ of COE for $24 \mathrm{~h}$. Results are presented as a proportion relative to the control and are the mean \pm standard deviation of three independent experiments. ${ }^{*} \mathrm{P}<0.05$. COE, Celastrus orbiculatus extract.

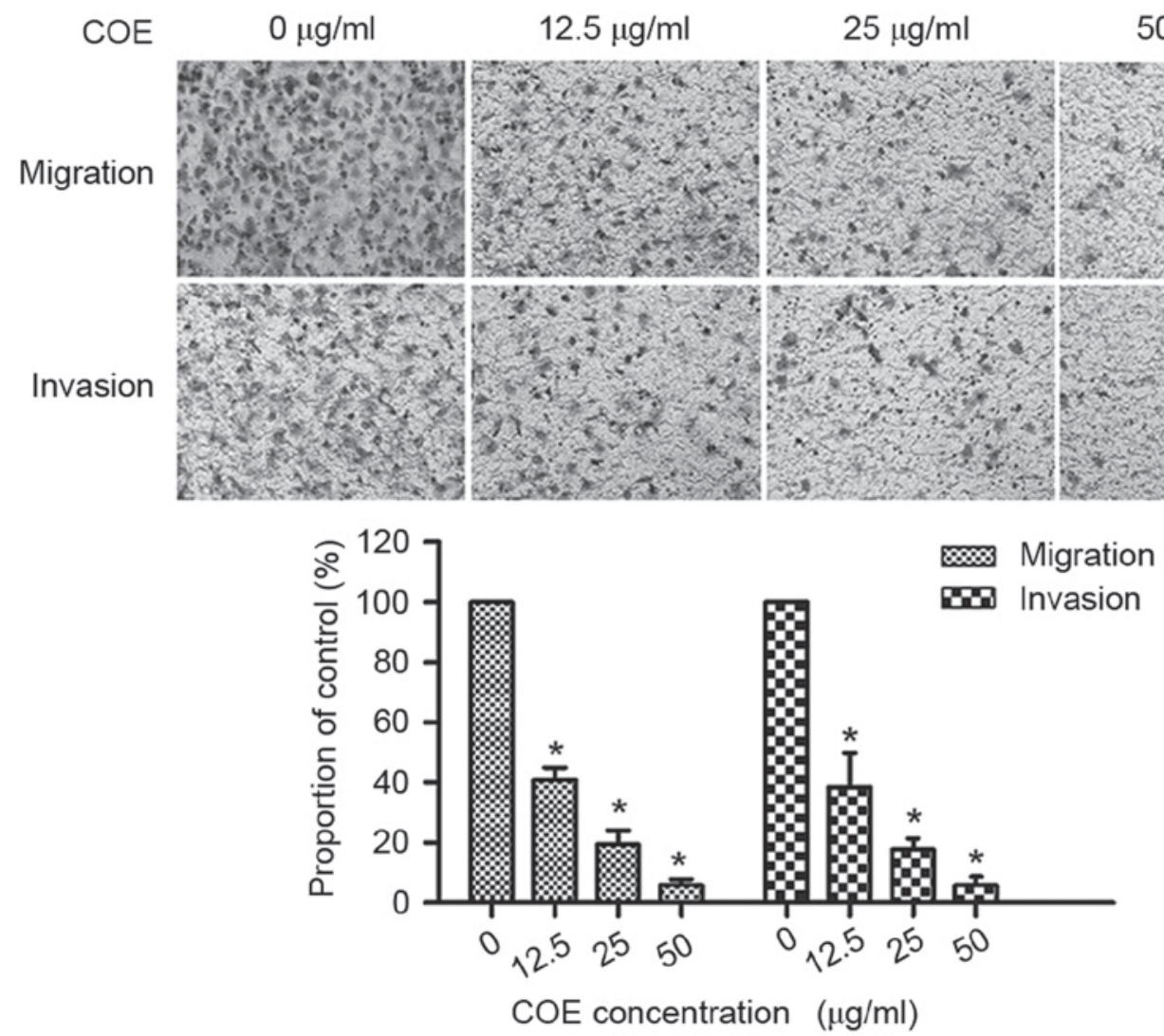

Figure 2. Effect of $\mathrm{COE}$ on invasion and migration of $5-8 \mathrm{~F}$ cells assessed using a Transwell assay. The invasion and migration ability of cells were quantified by counting the number of cells that invaded the underside of the polycarbonate membrane under a microscope (magnification, x200). Results are presented as the mean \pm standard deviation of three independent experiments. " $\mathrm{P}<0.05$. COE, Celastrus orbiculatus extract. 

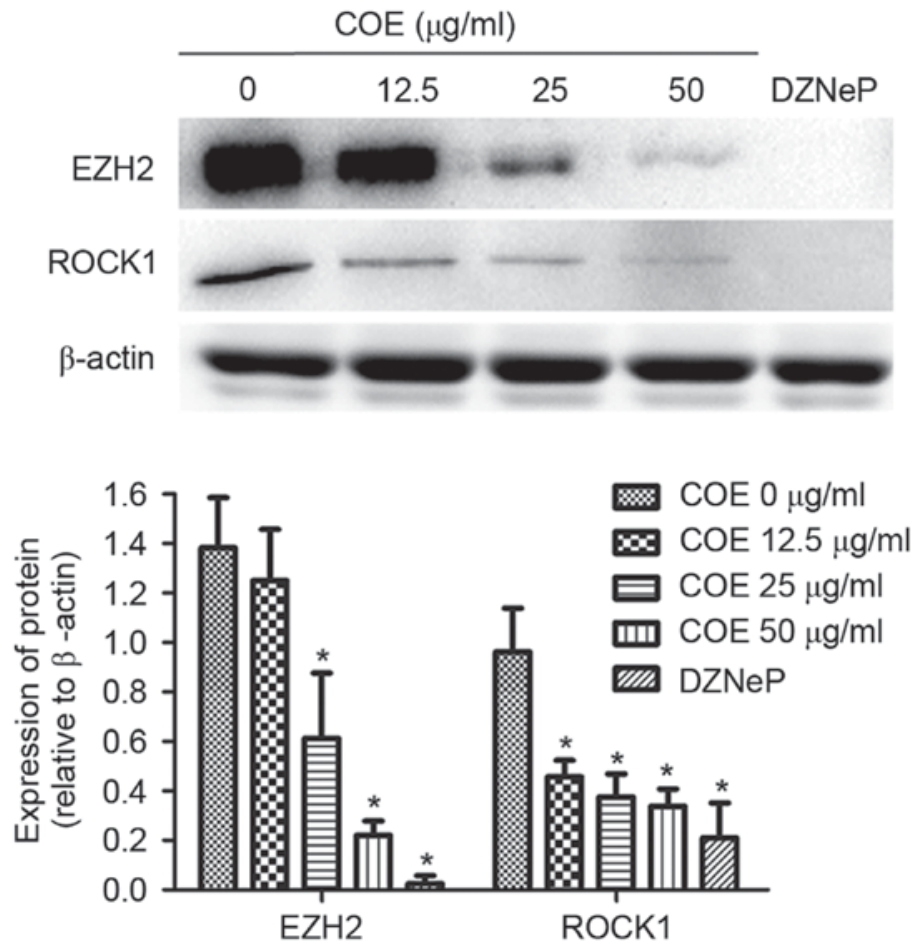

Figure 3. Protein expression levels of EZH2 and ROCK1 from 5-8F cells determined using western blot analysis. 5-8F cells were treated with COE $(0,12.5,25$ and $50 \mu \mathrm{g} / \mathrm{ml}$ ) or $2 \mu \mathrm{M}$ DZNeP. Results are presented as the mean \pm standard deviation of three independent experiments. "P<0.05. EZH2, enhancer of zeste homolog 2; ROCK1, Rho-associated coiled coil-containing protein kinase 1; COE, Celastrus orbiculatus extract; DZNeP, 3-Deazaneplanocin A.
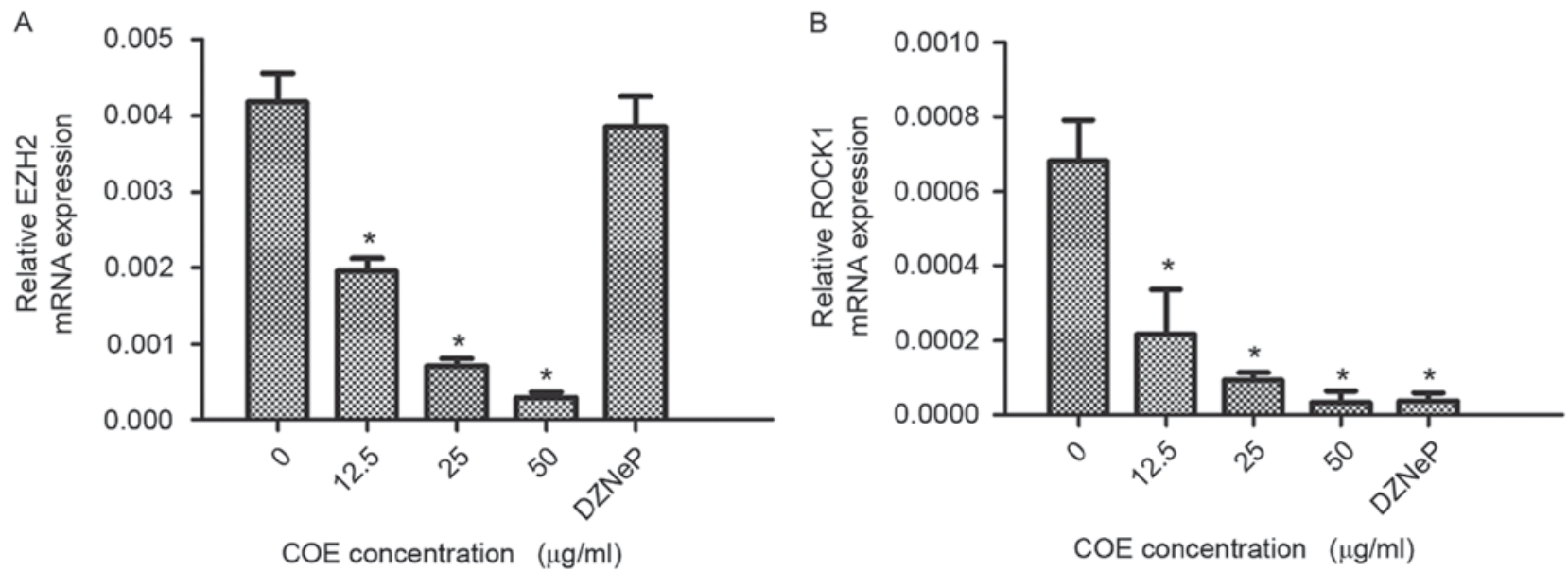

Figure 4. Reverse transcription-quantitative polymerase chain reaction determination of relative EZH2 and ROCK1 mRNA expression in 5-8F cells. Results are presented as the mean \pm standard deviation of three independent experiments. "P<0.05. (A) Relative EZH2 mRNA expression. (B) Relative ROCK1 mRNA expression. EZH2, enhancer of zeste homolog 2; ROCK1, Rho-associated coiled coil-containing protein kinase 1; DZNeP, 3-Deazaneplanocin A; COE, Celastrus orbiculatus extract.

was separated by SDS-PAGE (5-10\% gel) and transferred onto polyvinylidine difluoride membranes (Immobilon; EMD Millipore, Billerica, MA, USA). The membranes were blocked with $5 \%$ bovine serum albumin and incubated overnight at $4^{\circ} \mathrm{C}$ with primary antibodies. Following three washes with TBST, the membranes were incubated for $2 \mathrm{~h}$ at room temperature with HRP-conjugated goat anti-rabbit IgG. Immunoreactive protein bands were detected using an enhanced chemiluminescence system (GE Healthcare Life Sciences, Chalfont, UK). To quantify protein levels of the western blots, densitometric analysis was performed using ImageJ v1.46 software (National Institutes of Health, Bethesda, MD, USA).

Statistical analysis. SPSS software (version 16.0; SPSS, Inc., Chicago, IL, USA) was used to analyze the results of the present study. Results are presented as the mean \pm standard deviation and assessed by the two-tailed Student's t-test. To quantify protein levels of western blots, densitometric analysis was performed using ImageJ software (version 1.46; National Institutes of Health, Bethesda, MD, USA). $\mathrm{P}<0.05$ was considered to 
indicate a statistically significant difference. Experiments were performed at least three times.

\section{Results}

Effect of COE on viability of 5-8F cells. COE decreased viability of $5-8 \mathrm{~F}$ cells in a concentration-dependent manner (Fig. 1A). Additionally, COE increased the apoptotic rate of 5-8F cells in a concentration-dependent manner (Fig. 1B). However, no significant difference in the apoptotic rates of $5-8 \mathrm{~F}$ cells was identified for doses $<100 \mu \mathrm{g} / \mathrm{ml} \mathrm{COE}$ for $24 \mathrm{~h}$. Therefore, concentrations $<100 \mu \mathrm{g} / \mathrm{ml} \mathrm{COE}$ were selected for the subsequent experiments, to ensure that the effect of $\mathrm{COE}$ on NPC cells was not caused by direct cytotoxicity of COE.

COE inhibits migration and invasion in 5-8F cells. COE markedly decreased the number of cells which migrated and invaded the lower chamber, in a dose-dependent manner. As presented in Fig. 2, treatment with $\operatorname{COE}(12.5,25$ and $50 \mu \mathrm{g} / \mathrm{ml})$ inhibited $59.3,80.6$ and $94.21 \%$ of cell migration and inhibited 61.54 , 82.2 and $94.23 \%$ of cell invasion in $5-8 \mathrm{~F}$ cells, respectively. The results of the present study identified that COE inhibited migration and invasion of 5-8F cells in a dose-dependent manner.

COE inhibits protein expression of EZH 2 and ROCK1 in 5-8F cells. To determine the underlying molecular mechanism of COE in NPC cells, the expression levels of EZH2 and ROCK1 were analyzed. Treating cells with COE decreased EZH2 and ROCK1 protein expression levels in a dose-dependent manner. EZH2 and ROCK1 protein expression levels were significantly decreased following treatment with COE at $50 \mu \mathrm{g} / \mathrm{ml}$ and $2 \mu \mathrm{M}$ DZNeP, an inhibitor of EZH2, for $24 \mathrm{~h}$ (Fig. 3).

COE inhibits $m R N A$ expression of EZH 2 and ROCK1 in 5-8F cells. RT-qPCR was used to determine mRNA expression levels of EZH2 and ROCK1 in 5-8F cells. Cells treated with COE exhibited decreased EZH2 and ROCK1 mRNA expression levels in a dose-dependent manner. RT-qPCR revealed that EZH2 mRNA expression levels were significantly decreased following treatment with $\mathrm{COE}$ at $50 \mu \mathrm{g} / \mathrm{ml}$ for $24 \mathrm{~h}$; however, a similar effect was not observed with DZNeP treatment. ROCK1 mRNA expression levels were significantly decreased following treatment with various doses of COE and $2 \mu \mathrm{M}$ DZNeP for $24 \mathrm{~h}$. Results are presented in Fig. 4 . The results of the present study suggest that expression levels of EZH2 and ROCK1 mRNA were significantly decreased by $\mathrm{COE}$ in a dose-dependent manner in $5-8 \mathrm{~F}$ cells.

\section{Discussion}

COE serves diverse roles in antitumor activity through modulation of cell viability, apoptosis, angiogenesis, invasion and metastasis. Although a number of studies have suggested that the COE is associated with tumor metastasis $(8,14)$, its function in the EZH2/ROCK1 signaling pathway remains unclear. To identify potential therapeutic targets, elucidating the underlying molecular tumorigenic mechanisms of $\mathrm{COE}$ is required.

EZH2 overexpression has been identified in NPC, non-small cell lung cancer, chronic lymphocytic leukemia and breast cancer (15-17). Collectively, these studies suggest that
EZH2 is a novel target oncogene and pharmacological inhibition of EZH2 may be therapeutic for certain types of cancer.

The ROCK signaling pathway is one of the most important cellular invasion mechanisms. Activated Rho GTP binds to ROCK, changing the conformation of ROCK and exposing the catalytic domain so that downstream effector molecules may be phosphorylated. Subsequently, ROCK reorganizes the cytoskeleton and promote formation of focal adhesion (18). Previous studies have demonstrated that the regulation of human lung cancer cell movement by placental growth factor is primarily due to $\operatorname{ROCK}(19,20)$. Therefore, ROCK1 is associated with cancer growth, invasion and metastasis, and may be a target of tumor metastasis.

In order to determine the effect of COE on the EZH2/ROCK1 signaling pathway, a series of experiments were conducted in NPC cells. The function of COE was determined using an MTS cytotoxicity assay and flow cytometry. The increased dose of COE may be attributed to the decreased viability capacity and increased apoptotic rates.

The results of the present study demonstrated that COE serves a crucial role in decreasing tumor migration and invasion by regulation of the EZH2/ROCK1 signaling pathway. COE inhibited invasion and migration of 5-8F cells at low-toxic doses $(12.5,25$ and $50 \mu \mathrm{g} / \mathrm{ml})$, suggesting that inhibition of invasion and migration of 5-8F cells by $\mathrm{COE}$ was not due to its cytotoxic effect.

EZH2 and ROCK1 protein and mRNA expression levels were significantly decreased following COE treatment. The abrogation of EZH2 function by DZNeP decreased the protein and mRNA expression levels of ROCK1; however, DZNeP decreased the protein expression levels of EZH2 only. The results of the study of Girard et al (21) were consistent with those of the present study; DZNeP decreased protein expression levels, but not mRNA expression levels, of EZH2 in chondrosarcoma cells. The results of the present study, together with those of Girard et al (21), indicated that DZNeP may regulate EZH2 expression levels at the post-transcriptional level.

Previous studies have demonstrated that EZH2 is upregulated in NPC tissues. Overexpression of EZH2 was associated with an advanced clinical stage and increased risk of relapse, and EZH2 served as an independent poor prognostic factor for patients with NPC $(3,22)$. Therefore, ROCK1 may be partially involved in EZH2-induced progression of NPC.

EZH2 was overexpressed in NPC cell lines compared with normal nasopharyngeal cells. EZH2 knockdown by short hairpin RNA increased the expression of epithelial cadherin and markedly decreased the invasiveness and metastasis in NPC cells (23). ROCK1 serves a critical role in regulating cell migration and invasion $(7,19)$. The results of the present study demonstrated that the expression of EZH2 and ROCK1 was suppressed by COE at the level of transcription initiation. However, further studies are required to determine whether $\mathrm{COE}$ regulates $\mathrm{EZH} 2$ and ROCK1 directly and the underlying molecular mechanism for the association between EZH2 and ROCK1 in NPC.

$\mathrm{COE}$ was identified to be an inhibitor of EZH2 in NPC and inhibited the invasion and migration by downregulating the EZH2/ROCK1 signaling pathway. To the best of our knowledge, the present study is the first to identify the association between $\mathrm{COE}$ and the EZH2/ROCK1 signaling pathway. COE may therefore be used as a novel anticancer drug, particularly 
for types of cancer exhibiting increased expression of EZH2. The results of the present study identified the value of COE in treating metastatic NPC.

\section{Acknowledgements}

Not applicable.

\section{Funding}

The present study was supported by the National Natural Science Foundation of China (grant nos. 81573656, 81274141, 81450051 and 81403232), the Plans of Colleges and Universities in Jiangsu Province to Postgraduate Research and Innovation (grant no. KYZZ15-0368), the Foundation of SuBei People's Hospital (grant no. yzucms201409), the Natural Science Foundation of Jiangsu Province (grant no. BK20141280) and the second batch of scientific research projects of the National Traditional Chinese medicine clinical research base construction (grant no. JDZX2015254).

\section{Availability of data and materials}

The datasets used and/or analyzed during the current study are available from the corresponding author on reasonable request.

\section{Authors' contributions}

$\mathrm{XW}$ and $\mathrm{YH}$ designed the research, performed the experiments, analyzed data and wrote the paper. YC, YM, FY, XD, LT and HW performed the experiments. YQ and RG assisted with data acquisition and statistical analysis. YL performed the Celastrus orbiculatus extraction and provided all the reagents. All authors read and approved the final manuscript.

\section{Ethics approval and consent to participate}

Not applicable.

\section{Consent for publication}

Not applicable.

\section{Competing interests}

The authors declare that they have no competing interests.

\section{References}

1. Chang ET and Adami HO: The enigmatic epidemiology of nasopharyngeal carcinoma. Cancer Epidemiol Biomarkers Prev 15: 1765-1777, 2006.

2. Lee AW, Ng WT, Chan YH, Sze H, Chan C and Lam TH: The battle against nasopharyngeal cancer. Radiother Oncol 104: 272-278, 2012

3. Hwang CF, Huang HY, Chen CH, Chien CY, Hsu YC, Li CF and Fang FM: Enhancer of zeste homolog 2 overexpression in nasopharyngeal carcinoma: An independent poor prognosticator that enhances cell growth. Int J Radiat Oncol Biol Phys 82: 597-604, 2012.

4. Chang CJ and Hung MC: The role of EZH2 in tumour progression. Br J Cancer 106: 243-247, 2012.
5. Crea F, Paolicchi E, Marquez VE and Danesi R: Polycomb genes and cancer: Time for clinical application. Crit Rev Oncol Hematol 83: 184-193, 2012.

6. Shi Y, Pontrello CG, DeFea KA, Reichardt LF and Ethell IM: Focal adhesion kinase acts downstream of EphB receptors to maintain mature dendritic spines by regulating cofilin activity. J Neurosci 29: 8129-8142, 2009.

7. Newell-Litwa KA, Badoual M, Asmussen H, Patel H, Whitmore L and Horwitz AR: ROCK1 and 2 differentially regulate actomyosin organization to drive cell and synaptic polarity. J Cell Biol 210: 225-242, 2015.

8. Zhu Y, Liu Y, Qian Y, Dai X, Yang L, Chen J, Guo S and Hisamitsu T: Antimetastatic effects of Celastrus orbiculatus on human gastric adenocarcinoma by inhibiting epithelial-mesenchymal transition and NF- $\kappa \mathrm{B} /$ snail signaling pathway. Integr Cancer Ther 14: 271-281, 2015.

9. Zhang H, Qian Y, Liu Y, Li G, Cui P, Zhu Y, Ma H, Ji X, Guo S and Tadashi H: Celastrus orbiculatus extract induces mitochondrial-mediated apoptosis in human hepatocellular carcinoma cells. J Tradit Chin Med 32: 621-626, 2012.

10. Qian YY, Zhang H, Hou Y, Yuan L, Li GQ, Guo SY, Hisamits T and Liu YQ: Celastrus orbiculatus extract inhibits tumor angiogenesis by targeting vascular endothelial growth factor signaling pathway and shows potent antitumor activity in hepatocarcinomas in vitro and in vivo. Chin J Integr Med 18: 752-760, 2012

11. Li JJ, Yang J, LÜ F, Qi YT, Liu YQ, Sun Y and Wang Q: Chemical constituents from the stems of Celastrus orbiculatus. Chin J Nat Med 10: pp279-283, 2012

12. Zan K, Chen XQ, Wang Q and Cao L: Chemical constituents in stem of Celastrus orbiculatus. Chin Trad Herbal Drugs 38: 1455-1457, 2007.

13. Livak KJ and Schmittgen TD: Analysis of relative gene expression data using real time quantitative PCR and the 2(-Delta Delta C(T)) method. Methods 25: 402-408, 2001.

14. Zhu Y, Liu Y, Qian Y, Dai X, Yang L, Chen J, Guo S and Hisamitsu T: Research on the efficacy of Celastrus Orbiculatus in suppressing TGF- $\beta 1$-induced epithelial-mesenchymal transition by inhibiting HSP27 and TNF- $\alpha$-induced NF- $\kappa$ B/Snail signaling pathway in human gastric adenocarcinoma. BMC Complement Altern Med 14: 433, 2014.

15. Wang X, Zhao H, Lv L, Bao L, Wang X and Han S: Prognostic significance of EZH2 expression in non-small cell lung cancer: A meta-analysis. Sci Rep 6: 19239, 2016.

16. Rabello Ddo A, Lucena-Araujo AR, Alves-Silva JC, da Eira VB, de Vasconcellos MC, de Oliveira FM, Rego EM, Saldanha-Araujo F and Pittella Silva F: Overexpression of EZH2 associates with a poor prognosis in chronic lymphocytic leukemia. Blood Cells Mol Dis 54: 97-102, 2015.

17. Song X, Gao T, Wang N, Feng Q, You X, Ye T, Lei Q, Zhu Y, Xiong M, Xia Y, et al: Selective inhibition of EZH2 by ZLD1039 blocks H3K27 methylation and leads to potent anti-tumor activity in breast cancer. Sci Rep 6: 20864, 2016.

18. Croft DR, Crighton D, Samuel MS, Lourenco FC, Munro J, Wood J, Bensaad K, Vousden KH, Sansom OJ, Ryan KM and Olson MF: p53-mediated transcriptional regulation and activation of the actin cytoskeleton regulatory RhoC to LIMK2 signaling pathway promotes cell survival. Cell Res 21: 666-682, 2011.

19. Vigil D, Kim TY, Plachco A, Garton AJ, Castaldo L, Pachter JA, Dong H, Chen X, Tokar B, Campbell SL and Der CJ: ROCK1 and ROCK 2 are required for non-small cell lung cancer anchorage-independent growth and invasion. Cancer Res 72: 5338-5347, 2012.

20. Chen J, Ye L, Zhang L and Jiang WG: Placenta growth factor, PLGF, influences the motility of lung cancer cells, the role of Rho associated kinase, Rock1. J Cell Biochem 105: 313-320, 2008.

21. Girard N, Bazille C, Lhuissier E, Benateau H, Llombart-Bosch A, Boumediene K and Bauge C: 3-Deazaneplanocin A (DZNep), an inhibitor of the histone methyltransferase EZH2, induces apoptosis and reduces cell migration in chondrosarcoma cells. PLoS One 9: e98176, 2014

22. Lu J, Zhao FP, Peng Z, Zhang MW, Lin SX, Liang BJ, Zhang B, Liu X, Wang L, Li G, et al: EZH2 promotes angiogenesis through inhibition of miR-1/Endothelin-1 axis in nasopharyngeal carcinoma. Oncotarget 5: 11319-11332, 2014.

23. Tong ZT, Cai MY, Wang XG, Kong LL, Mai SJ, Liu YH, Zhang HB, Liao YJ, Zheng F, Zhu W, et al: EZH2 supports nasopharyngeal carcinoma cell aggressiveness by forming a co-repressor complex withHDAC1/HDAC2 and snail toinhibitE-cadherin. Oncogene 31: 583-594, 2012. 